Latin America, New Ruralities | 148

NORMA GIARRACCA'

\title{
Latin America, new ruralities, old and new collective action ${ }^{2}$
}

\section{Introduction}

ECLAC characterises the six-year period from 1998 to 2003 as the "lost six-years" for the region. In this sense, they refer to the poor performance of the main economic variables and recall what was known at the end of the 1980s as the "lost decade". The neoliberal discourse argued that, after the structural reforms put in place during the 1980s and 1990s, economies would grow and popular sectors would receive the spilling-over effects of that growth (the famous trickling down). It did not go like that: the growth rate of Gross Domestic Product (GDP) for the region shows a consistent decline since 1998, which reaches a critical point in 2002 due to the repercussions of the Argentine crisis. But this country was not the only one that showed the consequences of the "market policies" imposed by multilateral organisations and accepted by the local political leadership; Uruguay, Venezuela, Haiti and several countries in the Caribbean show negative annual rates of GDP growth and those that grow do so to very small degrees (ECLAC, 2003).

Since the 1980s, public policies in Latin America have tended to reorient state intervention, liberalise the economy, and open to international trade, taking wages as an adjustment variable. This way, unemployment rates grew and working conditions of those who kept their jobs became more precarious. Orthodox public policies such as the Austral Plan (1985) and the Convertibility Plan (1991) in Argentina, the mega-stabilisation of Bolivia (1985) and a series of stabilisation programmes such as those by Collor de Melo and Cardoso in Brazil between 1986 and 1999, and in Mexico between 1987 and 1994 - set in motion the institutional mechanisms that led to a transformation that was unprecedented during the $20^{\text {th }}$ century. Affected

\footnotetext{
'This text is a translation from the original: Giarracca Norma (1999). "Las ciencias sociales y los estudios rurales en la. Argentina durante el siglo XX."

2 This article has been translated by M. Eugenia Giraudo. This article was originally published in http://www.alternautas.net/blog/2021/2/2/latin-america-new-ruralities-old-and-new-collectiveaction
} 
agriculture and populations suffered the consequences of such macro-institutional changes.

Reca and Echeverría (cited by Spoor, 2002) argue that the participation of the agricultural sector in Latin America in its entirety went from representing 15\% of GDP in 1970 to $10 \%$ during the 1990 s. Apparently, in purely productive terms, the performance of agriculture was not better after deregulation and opening to external markets. According to specialists, there are no substantial differences between production and export trends compared to previous periods with strong state intervention, such as the sixties and seventies, but there are other sources of vulnerability that seem to emerge as a result of the opening to external markets, such as those derived from international volatility and internal distribution (Spoor 2002: 382-383).

In other words, the performance of macroeconomic variables did not improve and the social consequences were atrocious. In fact, the setback in the participation in national wealth of the broad majority was systematic for two decades: the "lost decade" - the eighties - and the nineties. But, in the latter, the indexes that measure poverty and extreme poverty grew on such a scale that the creators of the model designed and launched the famous "relief" programmes that managed to reduce them in recent years.

A report from ECLAC on the Social Panorama of Latin America 2002-2003 shows that, even if the percentages of population in poverty went down from $48.3 \%$ to 43.9\% between 1999 and 2002, in absolute terms there is an increase of 20 million people living in poverty and the number went from 200 to 220 million. The same occurs with levels of extreme poverty. Perhaps the most dramatic case is that of Argentina, whose leaders followed to the letter the dictates of the International Monetary Fund (IMF) indebting the country, giving away its natural resources and deregulating the economy. As a consequence, they created one of the most profound crises in national history: between 1999 and 2002, the poverty index almost doubled (from $23.7 \%$ to $45.4 \%$ ), while people in extreme poverty multiplied by three. In reality, Latin America was not the only one who suffered the consequences of the neoliberal model; the growth of the world economy was lower between 1980 and 2000 - a golden age of liberalism and deregulation in the name of growth - than during the seventies and eighties, a period of regulation and protectionism (Cassen, 2003). 
In this scenario, collective action takes place and new social actors emerge. Many of these new experiences have to do with the rural and agrarian world. According to NACLA's Report on Rural Movements (2000), in many parts of Latin America rural social movements have taken centre stage in their nations' politics. And this phenomenon is not exclusive to countries with a strong tradition of peasant struggles, like Brazil or Mexico, but it is also the case in countries with a significant history of urban labour struggles, such as Argentina, where new actors emerge, but necessarily articulated with the urban or industrial world.

At the end of the 1990s, protest became global and focused on international organisations that promoted these transformations (World Trade Organisation, International Monetary Fund, World Bank, etc.). Additionally, between end of 1993 and 1994 in many countries of Latin America there was innovative and significant resistance that recovered the experiences and struggles that had been developed since the beginning of the aforementioned decade.

In my opinion, at this moment it is possible to record three events that traversed the continent North to South (or South to North). First, the emergence of the Zapatista movement in Mexico, in the same moment as the country entered NAFTA (the North America Free Trade Agreement). This placed within the resistance space a new political thinking, for the first time with distance from the State, centred around autonomy and with a discursive logic closer to "expressive" aesthetics than to the "scientific" one used in the old leftist speeches. As Alain Badiou says, "the irruption of Chiapas fixes a measure - a distance - from the Mexican State; shows that such State can be identified and limited by a new form of political action" (Badiou, 2003: 13).

The development of information and communications technology enabled new forms of circulation for financial capital, one of the pillars of the new model, but also allowed for action at a distance from resistance groups. Perhaps the paradigmatic example of this situation was the spreading of the ideas of Zapatismo and its huge impact throughout a world population that was living with a certain unease about the 'de-humanising' advance of neoliberal capitalism. Today, many of the ideas of Zapatismo circulate in academic, cultural, and artistic spaces and find several allies in the European urban social world. In fact, the first Intercontinental Encounter for Humanity and against Neoliberalism - which took place in Chiapas at the end of July 1996 on the initiative of the Zapatista National Liberation Army (Ejército Zapatista de Liberación Nacional, EZLN) and had the presence of almost fifty 
resistance organisations from around the world - is considered the most important precedent of the series of protests that was known as the anti-globalization movement.

The second event occurs in Argentina and it is almost simultaneous with the Zapatista uprising. It was in one of the poorest provinces of Argentina, Santiago del Estero, which has a very high proportion of rural population. The rebellion began in its capital city, where people's livelihoods depend on public administration or services oriented towards agriculture. The 'pueblada' happened against the provincial state authorities and protested by burning buildings and going after corrupt politicians. This episode, in the middle of Carlos Menem's government, is remembered as the 'santiguenazo' and it is very important as a precedent for the 2001 crisis. From then on, the rate of electoral abstention in the province rose to $50 \%$ and a period of politicisation of the population began that led to a ferocious political and social persecution by the provincial power. This situation developed into a crisis in 2003 when the government tried to cover the murder of two young men because of its involvement in the crime.

Once again, people took over the streets, although this time in a pacific way, demanding justice, and political change. This irreconcilable relation between civil society and government representatives characterised Argentine politics since those initial moments in 1994. The events of $19^{\text {th }}$ and $20^{\text {th }}$ December 2001 marked the peak moment of this cycle at the national level. Despite the open process initiated with the government of Nestor Kirchner - which generated great expectations - the tension between "representatives-represented" and the questioning of the idea of 'representation' - key in liberal democracies - are central to the ideas of many of the new political forms that have emerged since then. ${ }^{3}$

The third event takes place in Ecuador. In fact, in June 1994, a few months after the events in Mexico and Argentina, indigenous people from the whole territory called for a mobilisation that stopped the country for two weeks. As Nina Pacari (1996), lawyer and leader of the Confederation of Indigenous Nationalities of Ecuador (Confederacion de Nacionalidades Indigenas del Ecuador, CONAIE) argues, the protest was organised against the Law of Agrarian Development, a key piece of the

\footnotetext{
${ }^{3}$ Electoral abstention in a country with mandatory vote went from a historical level that remained below $20 \%$ to $32 \%$ in a series of elections in the last year, with the exception of the presidential election.
} 
Latin America, New Ruralities | 152

plan of structural adjustment implemented by Sixto Duran Ballen: "The law approved by Congress called for the elimination of communal lands in favour of business agriculture, as well as other measures that favoured the interests of large landowners. Everything affecting indigenous people, peasants and small farmers of Ecuador was ignored" (Pacari, 1996: 23). In the following years, the indigenous movement converged with other movements, non-indigenous and urban, leading to the creation of the Pachakutik Movement, that during the nineties dabbled in the field of partisan politics. It was followed in 1997 by the removal of President Abdalá Bucará, the Constitutional Assembly of 1998, and the removal of President Jamil Mahuad in 2000 (Dávalos, 2003). Finally, towards the end of 2002, the Pachakutik Movement led the electoral alliance that allowed the electoral success of Coronel Lucio Gutierrez, but within a few months of forming a government, its members withdrew.

This dynamic process that took place over a decade transformed the destiny that historically was given to the indigenous people of Latin America and, once again, marked a key point in the political thinking of the region. Despite being a majority in several of our countries, native peoples never before had proposed to govern. Ecuador and then Bolivia put this issue on the regional agenda.

To this list of protests, resistance from peasants and indigenous people, 'puebladas', strengthening of organisations, and a number of other events that occurred in this period, we could add the Movement of Rural Workers Without Lands of Brazil - as well as the numerous peasant unions in this country, such as the National Confederation of Agricultural Workers (Confederação Nacional de Trabalhadores na Agricultura -CONTAG), the National Peasant Federation of Paraguay, the peasant and indigenous populations of Bolivia, Colombia, Peru, Chile, and Argentina. Most of them joined an organisation that grouped them together - the Latin American Coordination of Rural Organisations (Coordinadora Latinoamericana de Organizaciones del Campo - CLOC) - and, through it, into the international organisation Via Campesina.

In a similar way, a struggle over the preservation of natural resources unfolds throughout the continent in encounters of peasant organisations and small urban centres, such as the cases of Cochabamba and the protest against the privatisation of water in the southern region of the province of Tucuman in Argentina (Giarracca and Del Pozo, 2004). Mapuche populations in the South of Argentina protested against the installation of a mining company, alluding to what it would imply in 
terms of water waste; peasants and native communities in Bolivia were opposed to the export of Bolivian gas to the United States through Chile and led a rebellion that ended the government of Gonzalo Sánchez de Losada. In a similar direction, sociologist Bernard Duterme warns that in Chiapas the privatisation of public goods will transform the tension between indigenous people and the state into a confrontation between the latter and transnational corporations over the natural richness of the region (Duterme, 2004).

New demands and new aesthetics began to circulate in a significant way from one side of the continent to the other, while the main actors, who coincided in incorporating demands over natural resources to the historical claims over land, were not necessarily aware of one another. With the first years of the $21^{\text {st }}$ century, the struggle over natural resources is being consolidated as central and the concept of "territory" is replacing that of "land", as it includes and adds the richness of the subsoil.

The encounter between peasant and indigenous organisations in continental and international federations, the territorial mobility of some leaders and the universal principles of political order - such as "food sovereignty", respect for biodiversity, respect for gender equality, human rights - shaped the newness, created new senses and challenged us to think from new paradigms (see Via Campesina).

An additional paragraph should be dedicated to the process generated in the Mexican countryside in recent years. "The countryside cannot take it any longer", together with many other peasant and indigenous populations, reacted to the agrarian devastation that NAFTA created. In addition to these, there were peasant struggles such as those of Atenco, Estado de Mexico, against the destruction created by the Texcoco airport; those of the Montes Azules communities, in Chiapas, against evictions; those of Tepoztlán, Morelos, against a golf course; and those of ecologist peasants of Guerrero against transnational lumbering and in demand of the release of their prisoners (Bartra, 2003). [...]

\section{References}

Alfaro, M. I. 2001 "Los trabajadores citrícolas en Tucumán: las condiciones para la construcción de la protesta social" en Giarracca, N. (coord.) La protesta social en la Argentina. Transformaciones económicas y crisis social en el interior del país (Buenos Aires: Alianza Editorial). 
Latin America, New Ruralities | 154

Badiou, A. 1990 Se puede pensar la política (Buenos Aires: Nueva Visión).

Badiou, A. 2003 "Conferencia en Buenos Aires" in Acontecimiento (Buenos Aires) N 26.

Bartra, A. 2003 "El campo no aguanta más, a báscula” in La Jornada (México, DF) April 23.

Cassen, B. 2003 "Los efectos de la liberalización del comercio mundial" in Le Monde Diplomatique, Year V, N 51, September.

CEPAL 2003 Situación y Perspectivas. Estudio económico de América Latina y el Caribe (Santiago de Chile: ONU-CEPAL).

Cerdeiras, R. 2002 "La política que viene" in Acontecimiento (Buenos Aires: La Escuela Porteña) $N^{\circ} 23$.

Cerdeiras, R. 2003 "Las desventuras de la ontología. Biopolítica del imperio" in Acontecimiento (Buenos Aires: La Escuela Porteña) No 24-25, May.

Dávalos, P. 2003 "Plurinacionalidad y poder político en el movimiento indígena ecuatoriano" in Observatorio Social de América Latina (Buenos Aires: OSALCLACSO) $\mathrm{N}^{\circ} 9$.

De Sousa Santos, B. 2000 A crítica da razão indolente. Contra o desperdício da experiência (Brasil: Cortez Editora).

Duterme, B. 2004 "Diez ańos de zapatismo en Chiapas" in Le Monde Diplomatique (Buenos Aires) Year V, N 55, January.

Ejército Zapatista de Liberación Nacional 2003 "Chiapas: la treceava estela” en $<$ http://www.fzln.org.mx/modules.php?op=modload $\&$ name=News\&file=article\&si $\underline{\mathrm{d}=725}>$.

Giarracca, N. (comp.) 2001 ¿Una nueva ruralidad en América Latina? (Buenos Aires: CLACSO / ASDI).

Giarracca, N. 2003 "La protesta agrorrural en la Argentina" in Seoane, J. (comp.) Movimientos sociales y conflicto en América Latina (Buenos Aires: OSALCLACSO).

Giarracca, N. y Del Pozo, N. 2004 "To make water... Water privatization and social protest in Tucumán, Argentina" in Barnett, V. et al. Swimming against the Current: Integrated Water Resource Management and Gender in Latin America (Pittsburgh: University of Pittsburgh Press). 
Giarracca, N. y Teubal, M. 2001 "Crisis and agrarian protest in Argentina. The Movimiento de Mujeres Agropecuarias en Lucha in Argentina" in Latin American Perspectives, Vol. 28, № 6/121, November.

Grinberg, L. y Grinberg, R. 1984 Psicoanálisis de la migración y del exilio (Madrid: Alianza).

Hardt, M. y Negri, A. 2002 Imperio (Buenos Aires: Paidós).

Laclau, E. y Mouffe, Ch. 1987 Hegemonía y estrategia socialista. Hacia una radicalización de la democracia (Madrid: Siglo XXI).

NACLA 2000 Report on the Americas, Vol. XXXIII, N 5, March-April.

Orgaz García, M. 2003 La guerra del gas (La Paz: s/d).

Pacari, N. 1996 "Taking on the neoliberal agenda" en NACLA. Report on the Americas, Vol. XXIX, $\mathrm{N}^{\circ}$ 5, March-April.

Página/12. 2003 "La guerra no ha terminado" en Página/12, December 31.

Pérez, E. 2001 “Hacia una nueva visión de lo rural” en Giarracca, N. (comp.) ¿Una nueva ruralidad en América Latina? (Buenos Aires: CLACSO / ASDI).

Pérez, G. 2002 "Modelo para armar: complejidad y perspectiva de la protesta social en la Argentina reciente" in Argumentos (Buenos Aires: IIGG) N 1, December.

Petras, J. y Veltmeyer, H. 2001 “Are Latin American peasant movements still a force for changes? Some new paradigms revisited" in Journal of Peasant Studies (Londres: Frank Cass Journal) Vol. 28, $\mathrm{N}^{\circ}$ 2, January.

Schuster, F. 2002 "La trama de la protesta" in Cuadernos de coyuntura (Buenos Aires: Instituto Gino Germani, Universidad de Buenos Aires) $N^{\circ} 4$.

Schuster, F. y Pereyra, S. 2001 "La protesta social en la Argentina democrática. Balance y perspectivas de una forma de acción política” en Giarracca, N. et al. La protesta social en la Argentina. Transformaciones económicas y crisis social en el interior del pais (Buenos Aires: Alianza).

Spoor, M. 2002 "Policy Regimes and Performance of Agricultural Sector in Latin America and the Caribbean during the last three decades" in Journal of Agrarian Change (Londres: Blackwell Publishing) Vol. 2, N², July. 
Teubal, M. 2004 "Perspectiva sobre la tierra y la reforma agraria en América Latina" in Realidad Económica (Buenos Aires) N²00.

Teubal, M. y Rodríguez, J. 2002 Agro y alimentos en la globalización. Una perspectiva crítica (Buenos Aires: La Colmena).

Websites: CEPAL: <http://www.eclac.cl/>.

Vía Campesina: <http://www.viacampesina.org/> 